Cormac Redahan FFA RCSI, Jacek M. Karski MD FRCPC

\title{
Thyrotoxicosis factitia in a post-aortocoronary bypass patient
}

A 52-yr-old man presented with an evolving myocardial infarction and unstable angina. Previously, he had undergone aortocoronary bypass surgery for triple vessel disease and at that time was diagnosed as hypothyroid. He had been refractory to thyroxine treatment and now required $0.3 \mathrm{mg}$ thyroxine daily. On admission, he was hypertensive, tachycardic and found to be thyrotoxic secondary to excess thyroid hormone ingestion. Treatment with iopanoic acid was started. Despite medical therapy he continued to have unstable angina. Coronary angiography confirmed further triple vessel disease with blockage to his previous grafts. He was taken to surgery for coronary revascularization. On arriving in the intensive care unit he developed a thyroid storm. His temperature increased from 36.5 to $39.5^{\circ} \mathrm{C}$ requiring a cooling blanket and cold irrigation down a nasogastric tube. An esmolol infusion was started to control his persistent tachycardia but this depressed his myocardial contractility. He required amrinone and noradrenaline infusions as further inotropic support. For sedation and muscle relaxation, intravenous propofol infusion and doxacurium were given. Over the following $20 \mathrm{hr}$ the patient's condition stabilized. In conclusion, we describe the use of a short-acting beta blocker to avoid compromising an impaired myocardium during a thyroid storm which we could stop if the patient's cardiac condition deteriorated. In addition, amrinone, a phosphodiesterase inhibitor, was our inotrope of choice as it does not act on the already blocked beta adrenergic system.

Un homme de 52 ans se présente avec un infarctus du myocarde évolutif et une angine instable. Il avait déjà subi un pontage aortocoronarien pour une maladie des trois vaisseaux et était considéré comme hypothyroïdien. Résistant à la thyroxine, il

\section{Key words}

ANAESTHESIA: cardiovascular;

COMPLICATIONS: thyrotoxicosis;

HORMONES: thyroid.

From the Department of Anaesthesia, The Toronto Hospital, Toronto General Division, University of Toronto.

Address correspondence to: Dr. C. Redahan, Department of Anaesthesia, The Toronto Hospital, Toronto General Division, 200 Elizabeth Street, Toronto, Ontario, M5G 2C4 Canada. Accepted for publication 17th June, 1994. en recevait $0,3 \mathrm{mg}$ par jour. $A$ l'admission, il était hypertendu, tachycarde et thyrotoxique par prise exagérée d'hormone thyroïdienne. Le traitement est débuté avc de l'acide iopanoïque. Malgré le traitement médical, il continue de présenter de l'angine instable. L'angiographie coronarienne confirme l'atteinte des trois vaisseaux avec obstruction des trois greffons. On le transporte en chirurgie pour revascularisation. $A$ son retour à l'unité des soins intensifs, il développe une tempête thyroidienne. Sa température montre de 36,5 à $39,5^{\circ} \mathrm{C}$, ce qui nécessite une couverture refroidissante et une irrigation glacée par sonde nasogastrique. Une perfusion d'esmolol est mise en marche, pour le contrôle d'une tachycardie persistante ce qui déprime la contractilité myocardique. Des perfusions d'amrinone et d'adrénaline sont débutées. Pour la sédation et la relaxation musculaire, il reçoit une perfusion de propofol et de doxacurium. Pendant les 20 heures qui suivent, sa condition se stabilise. En conclusion, nous décrivons l'utilisation d'un $\beta$ bloquant à courte durée d'action pour éviter de léser un myocarde défaillant pendant une tempête thyroïdienne. Ce type de $\beta$-bloquant peut être interrompu facilement si nécessaire. $N$ 'agissant pas sur le système $\beta$-adrénergique déjà inhibé, l'amrinone, un inhibiteur des phosphodiestérases, a constitué notre inotrope de choix.

Anaesthetists rarely encounter patients with thyrotoxicosis which results from an excess of thyroid hormone ingestion (thyrotoxicosis factitia.) ${ }^{1}$ Management of thyrotoxicosis factitia (TF) is different from the routine preoperative preparation of the hyperthyroid patient with Graves' disease or toxic nodular goitre.

In this report we wish to present a patient with TF who presented for emergency coronary artery surgery and developed a thyroid storm in the immediate postoperative period.

\section{Case report}

A 52-yr-old man was admitted with a diagnosis of thoracic aortic dissection. Three days before admission he developed chest pain radiating through to his back. On the day of admission, his chest pain was unremitting and not relieved by sublingual nitroglycerine. In the emergency room he had an episode of ventricular fibrillation and was successfully cardioverted to sinus rhythm. He 
was hypertensive with a blood pressure $160 / 110 \mathrm{mmHg}$ and his heart rate was $120 \mathrm{bpm}$. An intravenous infusion of nitroprusside and metoprolol $100 \mathrm{mg}$ bd po was commenced. Transoesophageal 2-D ECHO excluded an aortic dissection. Following this episode he was admitted to the coronary care unit and an electrocardiogram showed ST segment elevation consistent with an evolving anterior myocardial infarction. His initial cardiac enzymes (CPK) done on the day of admission had increased to 2200 $\mathrm{U} \cdot \mathrm{L}^{-1}$.

He had a history of an inferior wall, myocardial infarction in 1988 which required coronary artery bypass graft surgery in 1989 to the left anterior descending, proximal circumflex and right coronary arteries. He was diagnosed hypothyroid in 1988 and was taking $0.3 \mathrm{mg} \mathrm{1-}$ thyroxine daily at the time of presentation. At the time the hypothyroidism was diagnosed his TSH concentration was high and he had low levels of $\mathrm{T}_{4}$. In January of 1992 his total $\mathrm{T}_{4}$ level was low at $41 \mathrm{nmol} \cdot \mathrm{L}^{-1}(\mathrm{~N}$ 55-155) while his TSH level was elevated at 67.7 $\mathrm{mU} \cdot \mathrm{L}^{-1}\left(0.9-4.6 \mathrm{mU} \cdot \mathrm{L}^{-1}\right)$. By September 1993 whilst taking $0.3 \mathrm{mg}$ of thyroxine his total $\mathrm{T}_{4}$ level had normalised to $96 \mathrm{nmol} \cdot \mathrm{L}^{-1}(55-155)$ but his TSH level still remained elevated at $81.42 \mathrm{mU} \cdot \mathrm{L}^{-1}$.

On the second day of hospitalization his blood pressure was within normal limits but his heart rate was still elevated at $120 \mathrm{bpm}$. He was persistently diaphoretic despite remaining apyrexial at $36.8^{\circ} \mathrm{C}$. Thyroid function tests showed free $T_{4}$ to be elevated at $63 \mathrm{pmol} \cdot \mathrm{L}^{-1}$ (normal value 9-23) and his TSH to be low at $0.17 \mathrm{mu} \cdot \mathrm{L}^{-1}$ (normal values $0.9-4.6$ ). These results combined with his clinical signs confirmed the diagnosis of hyperthyroidism secondary to excessive thyroid hormone ingestion. After consultation with the endocrine service the patient was given iopanoic acid $500 \mathrm{mg}$ bd $p o$.

Despite medical management with $i v$ nitroglycerin and heparin, oral metoprolol $(150 \mathrm{mg})$ and enteric coated acetylsalicylic acid he continued to have chest pain and emergency coronary angiography was performed. The right, left anterior descending and circumflex coronary arteries were occluded and the grafts to the left anterior descending artery and to the obtuse marginal artery were 99\% and $60 \%$ occluded respectively. The decision was made to perform aortocoronary bypass surgery and the patient received iopanoic acid $2 \mathrm{~g}$ before surgery. Premedication was with morphine $15 \mathrm{mg}$, perphenazine 5 $\mathrm{mg}$ im and metoprolol $150 \mathrm{mg}$ po. A right radial arterial line and large bore peripheral line had been inserted prior to induction of anaesthesia which was with fentanyl 2 $\mathrm{mg}$ and midazolam $2 \mathrm{mg}$ and maintained with isoflurane $1 \%$ while pancuronium $10 \mathrm{mg}$ was used as the muscle relaxant. A Swan-Ganz catheter was inserted into the patient's right internal jugular vein prior to surgery. In- traoperatively both the heart rate and systemic blood pressure were difficult to control. Attempts to reduce the heart rate and blood pressure were made with propranolol $2 \mathrm{mg} i v$ and a nitroglycerine infusion before cardiopulmonary bypass and this was effective in reducing the patient's heart rate from $120 \mathrm{bpm}$ to $90 \mathrm{bpm}$. Despite a nitroglycerine infusion, $2 \mathrm{mg}$ of propranolol, and isoflurane $1 \%$, the patient's systolic blood pressure ranged from 120 to $140 \mathrm{mmHg}$ before bypass. In order to separate from cardiopulmonary bypass, the patient required an intra-aortic balloon pump and an infusion of dopamine to maintain a cardiac index of $2.9 \mathrm{~L} \cdot \mathrm{min}^{-1} \cdot \mathrm{m}^{-2}$ despite an elevated pulmonary artery pressure $(54 / 32$ $\mathrm{mmHg}$ ). A persistent tachycardia remained at a rate of $120 \mathrm{bpm}$ which was unsuccessfully treated with a further dose of propranolol $1 \mathrm{mg} i v$. Due to the persistent tachycardia, his dopamine infusion was stopped in the operating room. Four aortocoronary bypass grafts had been completed, the left anterior descending artery was bypassed with the left internal mammary artery and saphenous vein grafts to the obtuse marginal, first diagonal, and posterior inter-ventricular branches.

After transfer to the cardiovascular intensive care unit (CVICU) his blood pressure was $100 / 60 \mathrm{mmHg}$ and a heart rate $125 \mathrm{bpm}$. Esmolol, $300 \mu \mathrm{g} \cdot \mathrm{kg}^{-1} \dot{i}$ was given over four minutes and an infusion of esmolol was started (50 $\mu \mathrm{g} \cdot \mathrm{kg}^{-1} \cdot \mathrm{min}^{-1}$ ) which was increased to 80 $\mu \mathrm{g} \cdot \mathrm{kg}^{-1} \cdot \mathrm{min}^{-1}$ to decrease his heart rate from 125 to $105 \mathrm{bpm}$. His cardiac index at admission was 2.8 $\mathrm{L} \cdot \mathrm{min}^{-1} \cdot \mathrm{m}^{-2}$ but decreased to $1.8 \mathrm{~L} \cdot \mathrm{min}^{-1} \cdot \mathrm{m}^{-2}$ after the infusion of esmolol was started. To maintain his cardiac index, norepinephrine and amrinone infusions were commenced. The patient was given a bolus of amrinone $100 \mathrm{mg}$ and an amrinone infusion at $10 \mu \mathrm{g} \cdot \mathrm{kg}^{-1} \cdot \mathrm{min}^{-1}$ was started which was increased to $14 \mu \mathrm{g} \cdot \mathrm{kg}^{-1} \cdot \mathrm{min}^{-1}$ with the cardiac index improving to $2 \mathrm{~L} \cdot \mathrm{min}^{-1} \cdot \mathrm{m}^{-2}$. Within $40 \mathrm{~min}$ of the patient's arrival in the intensive care unit, his temperature increased from $36.5^{\circ} \mathrm{C}$ to $39.5^{\circ} \mathrm{C}$. He was cooled with a cooling water blanket and repeated ice cold irrigation down his nasogastric tube and the temperature decreased to $37.5^{\circ} \mathrm{C}$ over the following six hours. Sedation with a propofol infusion was started at rate $20-30 \mu \mathrm{g} \cdot \mathrm{mg}^{-1} \cdot \mathrm{min}^{-1}$ and he was paralyzed with boluses of doxacurium $5 \mathrm{mg} i v$. During the first $12 \mathrm{hr}$ in the CVICU, blood pressure, heart rate and cardiac index were very labile and frequent changes of esmolol, propofol and norepinephrine infusions were necessary. The lungs were ventilated artificially and required an $\mathrm{FIO}_{2}$ from 70 to $90 \%$ and PEEP of $10 \mathrm{~cm} \mathrm{H}_{2} \mathrm{O}$ to maintain an oxygen haemoglobin saturation $>94 \%$. Over the next 24-48 hr his clinical status improved, the IABP was removed and the amrinone discontinued. An esmolol infusion from $20-80 \mu \mathrm{g} \cdot \mathrm{kg}^{-1} \cdot \mathrm{min}^{-1}$ was continued 
until the fifth postoperative day. The postoperative course was complicated by extreme agitation whenever the sedation was stopped which was treated with haloperidol 25-5 $\mathrm{mg} i v$ boluses.

On the third postoperative day, the patient developed ventricular tachycardia requiring cardioversion and an amiodarone infusion $\left(1200 \mathrm{mg} \cdot 24 \mathrm{hr}^{-1}\right)$ was started. His free $T_{4}$ concentration taken on the third postoperative day was $23 \mathrm{pmol} \cdot \mathrm{L}^{-1}$ while his TSH had increased to 0.71 $\mathrm{mu} \cdot \mathrm{L}^{-1}$. He developed pneumonia while in the intensive care unit and required ventilation for nine days. He was weaned from the ventilator and the trachea was extubated on the ninth day and discharged from the unit on day 12 after surgery.

\section{Discussion}

We were faced with a patient with known ischaemic heart disease and an unstable angina who presented with an uncommon form of thyrotoxicosis. Thyrotoxicosis factitia is rarely seen in the adult patient population. There is no report in the medical literature describing perioperative thyroid storm related to this form of thyrotoxicosis. Thyrotoxicosis has a profound effect on the heart and circulation increasing the heart rate, blood volume, myocardial contractility and cardiac work which leads to myocardial hypertrophy and reduced myocardial contractile reserve. ${ }^{2}$ Thyrotoxicosis may precipitate angina or myocardial infarction in patients with or without underlying coronary artery disease. It can also precipitate atrial fibrillation. ${ }^{3,4}$

The combination of tachycardia and hypertension which the patient had, contributed to his continuing myocardial ischaemia. In the coronary care unit nitroprusside infusion had been started which helped to control blood pressure but exacerbated his tachycardia. His heart rate proved more difficult to manage and had been poorly controlled with beta blockers even before surgery. The urgency for surgery was based on his coronary angiograms and the poor response of unstable angina to medical management.

The patient's rapid increase in temperature during the early postoperative period combined with his labile blood pressure and persistent tachycardia suggested to us an ongoing thyroid storm. It has been postulated that the primary cause of a thyroid storm is a marked hypersensitivity to increased catecholamine secretion. This in turn leads to the increased beta adrenergic effect. ${ }^{5}$ Our aim was to bring his hyperdynamic circulation under control without long-term compromise of an impaired myocardium. We wanted to control his heart rate without affecting his blood pressure. Esmolol, with rapid onset and short duration of action, allowed us to do this safely. We were concerned about using longer-acting beta- blockers such as propranolol as its negative inotropic effects would not have been reversed so rapidly if needed.

Our use of amrinone, a phosphodiesterase inhibitor and norepinephrine with alpha agonist actions as our inotropes of choice was because amrinone does not act via beta receptors. The most effective form of sedation for this patient was a continuous infusion of propofol and we were concerned that the use of benzodiazepines might have a profound hypotensive effect. Indeed, when we later changed his sedation to morphine and haloperidol we found them to control his agitation poorly and had to revert to a propofol infusion.

The preoperative management of thyrotoxicosis factitia from excess thyroid hormone ingestion is different from the management of thyrotoxicosis from excessive endogenous thyroid hormones. The use of anti-thyroid medication, propylthiouracil or methimazole, is of no benefit as it inhibits thyroid hormone synthesis. In thyrotoxicosis factitia, the peripheral conversion of $T_{4}$ to the more active form of $T_{3}$ needs to be inhibited. This is done with iopanoic acid, an oral radiological contrast which contains iodine. Iopanoic acid also blocks hormone released from the thyroid gland. Iopanoic acid has structural similarity to thyroxine and behaves as a competitive inhibitor of 5 -mono deiodinase, the enzyme responsible for the conversion of $T_{4}$ to $T_{3}$. Bal and Nair ${ }^{6}$ showed that hyperthyroid patients may be quickly brought to a euthyroid state with iopanoic acid. They found that the free $T_{3}$ level was decreased by $50 \%$ on day one of treatment and by $68 \%$ at $48 \mathrm{hr}$. Wang et al. ${ }^{7}$ were able to show a considerable reduction of the serum $T_{3}$ concentration but were unable to show a sustained long-term effect. Other papers have confirmed the safety and efficacy of iopanoic acid in patients requiring thyroidectomy ${ }^{8}$ and in infants with Graves disease. ${ }^{9}$ Beta blockers have an established role in treatment of TF as they have a beneficiary effect on tachycardia and hypertension and also inhibit peripheral conversion of $T_{4}$ to $T_{3}$. Barbiturates have been advocated for sedation and relief of irritability in TF. They enhance the hepatocellular binding of thyroid hormone thus increasing thyroxine turnover and clearance. ${ }^{10}$

\section{Summary}

This patient presented with multiple diagnostic and therapeutic problems. He had unstable angina due to partial stenosis of his aortocoronary grafts and occluded native coronary arteries. This was exacerbated by hyperthyroidism due to ingestion of excessive doses of thyroid hormone replacement (1-thyroxine). He required urgent myocardial revascularization and despite medical treatment for TF with iopanoic acid, he developed a postoperative thyroid storm which was successfully treated with an intravenous infusion of esmolol. Since esmolol de- 
pressed his myocardial contractility in the postoperative period we opted to use amrinone and norepinephrine infusions as further inotropic support for his heart.

\section{References}

1 Greer MA. Disorder of the thyroid. In: Stein JH (Ed.). Internal Medicine. Boston: Little Brown, 1987; 1925.

2 Woeber KA. Thyrotoxicosis and the heart. N Engl $\mathrm{J}$ Med 1992; 327: 94-8.

3 Phull PS, Collins CE, Norell MS, Thomas DJB. Variant angina in thyrotoxicosis. Br J Clin Pract 1993; 47: 17-8.

4 Glikson M, Freimark D, Leor R, Shechter M, Kaplinsky $E$, Rabinowitz $B$. Unstable anginal syndrome and pulmonary oedema due to thyrotoxicosis. Postgrad Med J 1991; 67: 81-3.

5 Greer MA. Disorder of the thyroid. In: Stein JH (Ed.). Internal Medicine. Boston: Little Brown, 1987; 1930.

6 Bal C. Nair N. The therapeutic efficacy of oral cholecystographic agent (iopanoic acid) in the management of hyperthyroidism. J Nucl Med 1990; 31: 1180-2.

7 Wang Y-S, Tsou C-T, Lin W-H, Hershman JM. Long term treatment of Graves' disease with iopanoic acid (Telepaque). J Clin Endocrinol Metab 1987; 65: 697-82.

8 Baeza A, Aguayo J, Barria M, Pineda G. Rapid preoperative preparation in hyperthyroidism. Clin Endocrinol (Oxf) 1991; 35: 439-42.

9 Transue D, Chan J, Kaplan M. Management of neonatal Graves disease with iopanoic acid. J Pediatr 1992; 121: 472-4.

10 Sturgis T, Rosenbaum RL, Gerhard H. Thyroxine overdose caused by a suicide attempt in an adult. $\mathrm{N} J$ Med 1988; 85: 665-6. 